\title{
Nyumba Kumi Strategy of Community Policing And Its Impact on Curbing Crime; Empirical Assessment From Kenya.
}

\author{
Mark Leting \\ Lecturer Kibabii University \\ Josphine Chepchirchir \\ Masinde Muliro University of Science and Technology
}

\begin{abstract}
The purpose of this study was to explore the impacts of nyumba kumi community policing strategy on crime prevention in Kenya. Data was analyzed using descriptive statistics in which frequency distributions; percentages and mean in each item was calculated. The findings of the study were that there was a Nyumba Kumi community policing strategy for curbing crime in Kenya. The participants agreed that nyumba kumi community policing strategies, political support and good will of the government for nyumba kumi community policing strategy and police administration had positive impact on nyumba kumi community policing strategy in curbing crime rate in Kenya. The conclusion was that; nyumba kumi community policing initiatives can be effective where the jurisdiction have achieved some degree of political stability and shared values. Police who are poorly paid and have low morale as a result of serious management problems and corruption are not likely to be motivated to cooperate with the community and there may be a general lack of respect for community policing strategy.
\end{abstract}

Keywords:- Nyumba kumi, Community Policing, Curbing Crime

Paper type: Research Paper

\section{INTRODUCTION}

The idea that a closer partnership between the police and local residents could help reduce crime and disorder began to emerge throughout the 1970s. One of the reasons why this consideration was appealing to police departments was because the recognition that the police and the community were co-producers of police services spread the blame for increasing crime rates (Skogan and Hartnett). An innovative project in San Diego specifically recognized this developing theme by encouraging line officers to identify and solve community problems on their beats (Boydstun and Sherry).Community-based policing (CBP) is an approach to policing that brings together the police, civil society and local communities to develop local solutions to safety and security concerns. This paper, published by Saferworld, assesses outcomes of and lessons learned from two CBP pilotsites supported by Saferworld as part of its broader programme of police reform in Kenya. CBP improves public trust in the police, cooperation between police, citizens and community, and develops stakeholder capacity for security sector reform (SSR).

\subsection{LITERATURE REVIEW}

\subsection{Community-Based Policing in Kenya}

The Government of Kenya (2008) in the publication“ Implementing community-based policing in Kenya' quotes the Former Secretary General of the UN, Kofi Annan (2008) "There can be no security without development and no development without security, and neither can be sustained in the long term without being rooted in the rule of law and respect for human rights." There is increasing recognition that without security there can be no development. Insecurity hinders socio-economic growth in different ways: threats to physical security, the absence of safe living environments, dangers that prevent people from achieving sustainable livelihoods, and the impact upon health and education services.In Kenya, police reform is a critical issue not only for community safety and economic development, but because there is intense popular demand for reduced crime and better police performance. Since 2003, Saferworld, in collaboration with its local partner PeaceNet, has developed and implemented a CBP programme in Kenya. This publication documents the main activities carried out by Saferworld and its partners in support of Kenyan police reform during the last five years, including training for police and community leaders; development of a national policy on community policing; strategic planning with the police; and establishing CBP projects at two pilot sites - Isiolo and Kibera. It aims to increase understanding of the concept of CBP by illustrating how it is working in the Kenyan context. By examining both the achievements and the challenges of CBP in Kenya, the booklet goes on to suggest some lessons that can be learned from this experience. 


\subsection{Neighbourhood Watch Nyumba Kumi Community Policing Strategies}

The creation of local crime alertness programs such as Neighbourhood Watch is one of the applications of community policing strategies in crime prevention at local household level. (Murray 2005). Outreach activities, such as visits to schools or sports and music events, which seek to establish closer relations between police and those segments of the community considered most at-risk of committing crime (Lawday, 2000). The advent of community policing should be understood not only as a quest for more effective and accountable policing, but also as part of a wider public sector reform movement (Taylor, Francis and Wong, 2001). Public sector organizations around the world have sought to improve both accountability and outcomes, and have adopted reforms that champion collaborations between the public, private, and civil society as part of a wider, consumer-based approach to the provision of public services (Wisler \& Onwudiwe, 2009).Community policing may focus more on local-based initiatives, but it is also directly related to higher-level accountability and dialogue mechanisms such as civilian police boards or watchdog agencies (Wisler \& Onwudiwe, 2009). In Western industrialized democracies, community policing is seen as a relatively new approach, but it can also be understood as an attempt to recover earlier traditions of policing. The police officer on the beat who knows the locals and their problems a typical community policing strategy is also the symbol of an earlier, supposedly golden, age of policing (Wisler \& Onwudiwe, 2009).Typical community policing programs such as Neighbourhood Watch can be seen as a partial return to the more informal civilian policing that was the norm before the emergence of modern bureaucratic policing in industrialized countries (Lawday, 2000).

According to Wisler \& Onwudiwe (2009)some commentators go as far as to argue that community policing has been swept away by homeland security, but others maintain that the two tendencies are compatible as intelligence gathering, however defined, still requires close relationships with the public (Murray 2005). Stability and community cohesion: The country or jurisdiction should have achieved some degree of political stability and shared values (Taylor, Francis and Wong, 2001). Police outreach to and collaboration with community however defined was difficult to achieve in periods of political turmoil and if the society is still driven by factionalism (Dupont 2007).R1; Many of the participants had agreed with the fact that neighborhood watch nyumba kumi community policing strategy had effect on curbing crime in Kenya.

\subsection{Political Support and Neighborhood Watch Community Policing Strategy}

Local security contracts to encourage co-production of security through different institutional and civil society actors, such as local schools, businesses, town halls, and judges (Dupont 2007). The contracts are strengthened by an array of new crime-prevention concepts, including uncovering potential threats to the community and targeting them with intelligence-led policing (Lawday 2000). The contrast between community policing approaches in industrialized and developing countries may be that in Western democracies they are focused on the police searching for community, while in developing countries it is the community in search of policing (Wisler and Onwudiwe 2009). A brazen example of the manipulation of community policing language is from Zimbabwe, where freedom of expression, assembly, and association have been curtailed, and the police accused of torturing human rights advocates in custody (Amnesty International 2007). Contradicting such accusations were the words of the Zimbabwe Police Commissioner who in 2007 reported to an international policing forum that: "The thrust of the Zimbabwe Republican Police has been law enforcement with the consent of the public and in cooperation with international agencies. This has found expression through community policing programs, interagency approach and cooperation with regional and international partners. In an endeavor to reach a wide cross section of people, Community Relations Officers have been seconded to every police station, district, province and national levels to market the idea of police working together with people" (Zimbabwe Police 2007).R2; A majority of the participants of the sampled participants had agreed that there was some political support of the neighbourhood watch Nyumba Kumi community policing strategy.

\subsection{Police Administration and Neighbourhood Watch Community Policing Strategy}

Community policing requires local flexibility, so the police organization must have the willingness and capacity to confer authority to the appropriate command levels (Kempa 2007). Part of this capacity depends on the knowledge and skills of those who will assume the social justice (Goldsmith and Lewis 2000). Under emerging consumerist approaches to public services, citizens' support is critical to police effectiveness and the police are required to be more accountable to the citizens they serve (Brogden and Nijhar 2005).Given the limitations on expansion of the welfare State, the community is being asked to share more of the responsibility for addressing crime and disorder (Segrave and Ratcliffe 2004). Policing is becoming more proactive in preventing crime and disorder and the stronger educational background of police means that they can perform a wider range of prevention functions and collaborate with other agencies (Murray 2005).R3; A majority of the sampled participants had agreed that the police administration had impacted on the neighbourhood watch nyumba kumi community policing strategy in their resident/area of work in curbing crime rate in kenya. 
Independent variables

Dependent variable

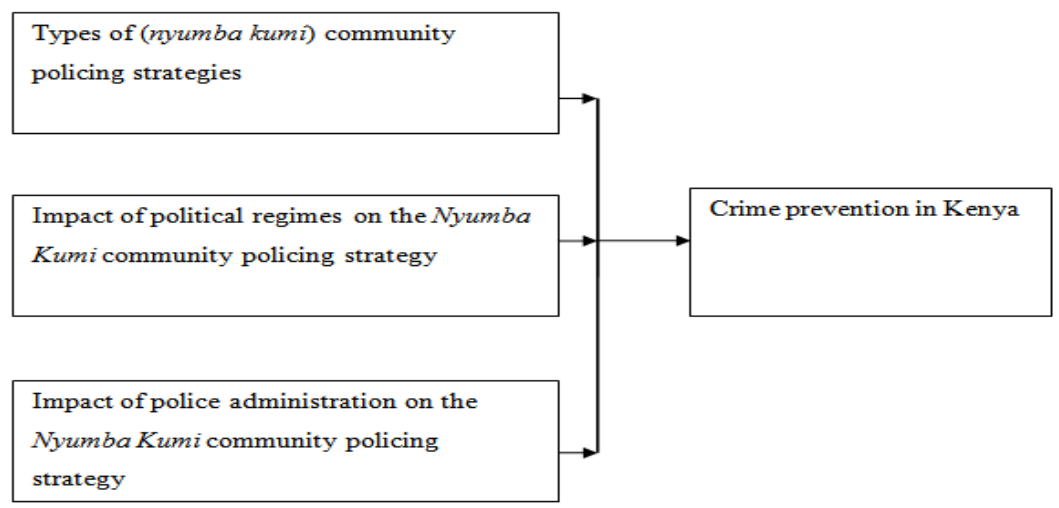

\subsection{METHODOLOGY}

\subsection{Sampling and Data Collection}

Since the actual total target study population was all participants in the study area, which cannot be candidly extracted and determined, the researcher used convenience sampling method following purposive sampling approach, where participants were identified and interviewed as they assist the researcher on where to get the next respondents. To select the chief and the administration police census method was used to include all of them in the study sample of 60 was obtained as shown in Table 3.1 below.

Table 3.1, Sampling Matrix

\begin{tabular}{|l|r|r|}
\hline Category & Population (N) & Sample(n) \\
\hline Participants Women/Men & unknown & Convenience Sampling =51 \\
\hline Administration police & 5 & 5 \\
\hline 1-Chief/3-sub-chiefs & 4 & 4 \\
\hline Total & Uncertain & $\boldsymbol{n = 6 0}$ \\
\hline
\end{tabular}

\subsection{Data Analysis and Results}

Bio data of the Respondents is presented in Table 4.1, the results showed that the males were $81.7 \%$ $(49 / 60)$ and females were $18.3 \%(11 / 60)$, thus there were more male participants than female participants in this study

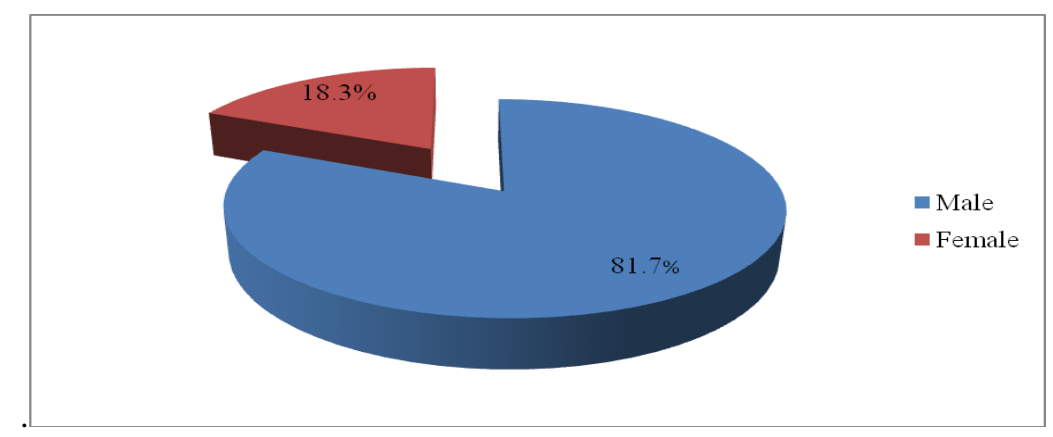

Figure 4.2: Participants by Gender

\subsection{Neighbourhood Watch Nyumba Kumi Community Policing in Curbing Crime;}

Many, 76.7 percent (with $41.7 \%$ strongly agreed and $35.0 \%$ agreed) of the participants had agreed with the fact that neighborhood watch nyumba kumi community policing strategy had effect on curbing crime in Kenya. Mean value on the 5-point likert rating scale of $[x: 1,2,3,4,5]$ was also calculated using sum of $f x=$ 119 divided by sum of $f=60$ as shown in Table 4.3. The mean value calculated was $119 / 60=1.98$, which was 
interpreted as to represent the fact that most of the participants had agreed with the fact that neighborhood. Watch nyumba kumi community policing strategy had effect on curbing crime in Kenya.

Table 4.3, Neighborhood Watch Nyumba Kumi Community Policing in Curbing Crime

\begin{tabular}{|l|r|r|r|r|}
\hline Rating Scores (x:1-5) & Frequency (f) & $\mathbf{x}$ & \multicolumn{1}{|c|}{$\mathbf{f}$} & Percentage (\%) \\
\hline 1-Strongly Agree & 25 & 1 & 25 & 41.7 \\
\hline 2-Agree & 21 & 2 & 42 & 35.0 \\
\hline 3-Neutral & 7 & 3 & 21 & 11.7 \\
\hline 4-Disagree & 6 & 4 & 24 & 10.0 \\
\hline 5-Strongly Disagree & 1 & 5 & 5 & 1.6 \\
\hline Total & $\mathbf{6 0}$ & & $\mathbf{1 1 9}$ & $\mathbf{1 0 0 . 0}$ \\
\hline
\end{tabular}

\subsection{Impact of Political Support on Ten Household Watch Community Policing}

A majority of the participants 91.7 percent of the sampled participants had agreed by indicating 'Yes' that there was some political support of the neighborhood watch (Nyumba Kumi) community policing strategy in their resident. The sampled participants were asked to rate the impact of political support and good will of the government for Neighbourhood Watch (Nyumba Kumi) community policing strategy in the residential/area of work in curbing crime rate in the location, using the 5-point likert scale rating shown as: 1-strongly agree, 2agree 3-neutral 4-disagree and 5-strongly disagree. The responses obtained were tabulated as shown in Table 4.4 .

Table 4.4, Impact of Political Support often Household Watch Community Policing

\begin{tabular}{lrrrr}
\hline Rating Scores (x:1-5) & Frequency (f) & x & fx & Percentage (\%) \\
\hline 1-Strongly Agree & 35 & 1 & 35 & 58.3 \\
2-Agree & 22 & 2 & 44 & 36.7 \\
3-Neutral & 3 & 3 & 9 & 5.0 \\
4-Disagree & 0 & 4 & 0 & 0.0 \\
5-Strongly Disagree & 0 & 5 & 0 & 0.0 \\
\hline Total & $\mathbf{6 0}$ & & $\mathbf{8 8}$ & $\mathbf{1 0 0 . 0}$ \\
\hline
\end{tabular}

As shown in Table 4.4: Majority, 95.0percent (with 58.3\% strongly agreed and $36.7 \%$ agreed) of the participants had agreed that political support and good will of the government for Neighbourhood Watch (Nyumba Kumi) community policing strategy in the residential/area of work had effect on curbing crime in Kenya. The mean value obtained was calculated using sum of [ $f x=88$ ] divided by sum of $f=60$ as shown in Table 4.4. The mean value calculated was $88 / 60=1.47$, which was interpreted as to agree that almost all participants had agreed that political support and good will of the government for Neighbourhood Watch (Nyumba Kumi) community policing strategy in the residential/area of work had effect on curbing crime in Kenya .

\subsection{Impact of Police Administration on Neighborhood Watch Community Policing}

The participants were asked to rate the impact of Police Administration on the Neighbourhood Watch (Nyumba Kumi) community policing strategy in the resident/area of work on curbing crime in Kenya using the 5-point likert scale rating shown as: 1-strongly agree, 2-agree 3-neutral 4-disagree and 5-strongly disagree. The responses obtained were tabulated as shown in Table 4.5.

Table 4.5, Impact of Police Administration on Neighbourhood Watch Community Policing

\begin{tabular}{|l|r|r|r|r|}
\hline $\begin{array}{l}\text { Rating Scores (x:1- } \\
\text { 5) }\end{array}$ & Frequency (f) & $\mathbf{x}$ & $\mathbf{f x}$ & Percentage (\%) \\
\hline 1-Strongly Agree & 20 & 1 & 20 & 33.3 \\
\hline 2-Agree & 22 & 2 & 44 & 36.7 \\
\hline 3-Neutral & 12 & 3 & 36 & 20.0 \\
\hline 4-Disagree & 3 & 4 & 12 & 5.0 \\
\hline 5-Strongly Disagree & 3 & 5 & 15 & 5.0 \\
\hline Total & $\mathbf{6 0}$ & & $\mathbf{1 2 7}$ & $\mathbf{1 0 0 . 0}$ \\
\hline
\end{tabular}

As shown in Table 4.5: majority 70.0 percent (with 33.3\% strongly agreed and $36.7 \%$ agreed) of the participants had agreed that the police administration had impacted on the neighbourhood watch (nyumba kumi) community policing strategy in their resident/area of work in curbing crime rate in Kenya . Using the 5-point likert rating scale of $[x: 1,2,3,4,5]$ a mean value was also calculated using sum of [ $f x=127]$ divided by sum of $f=60$ as 
shown in Table 4.5. The mean value calculated was $127 / 60=2.12$. The mean value of 2.12 was less than 2.4999 in the 5-point scale which represents a general rating that the participants were in agreement with the fact that the police administration had impacted on the neighborhood watch (nyumba kumi) community policing strategy in their resident/area of work in curbing crime rate in the Kenya. This was rated as participants had agreed that the police administration had impacted on the neighbourhood watch (nyumba kumi) community policing strategy in their resident/area of work in curbing crime rate in Kenya.

\subsection{Conclusion of the Study}

The neighbourhood watch community policing initiatives can be effective where the jurisdiction have achieved some degree of political stability and shared values. Police outreach activities and collaboration with community cannot be achieve in periods of political turmoil and factionalism. Despite of the implementation problems there continues to be a commitment to community policing initiatives around the globe, and continuing reports of positive impacts, even if they are modest. Consequently, a more useful approach to understanding the possibilities of exporting the community policing model comes from those who have identified the conditions that are likely to impact on attempts to implement it in new settings.

\subsection{Recommendations of the Study}

Police cooperation with and the consent of, the community is highly subjective and politically malleable. Therefore there is need for the localization of policing strategies and communication with residents. Literature also shows that around the world, almost every evaluation of policing operations whether by governments, civil society organizations, international bodies, or private consultants continues to recommend reforms based on community policing principles (Kempa 2007). Thus the study recommended that the police administration need to make its officers to become more knowledgeable about crime in a specific neighbourhood or location through practicing localized ten households' neighbourhood watch community policing strategies. However, community policing has fallen out of favor in Anglo-Industrialized countries, has never quite been implemented in Continental European countries, is a dismal failure in developing countries, and is a farce in centralized and authoritarian countries.

\subsection{Suggestion for Further Studies}

Further studies on the usefulness of nyumba kumi community policing model in curbing crime are recommended in other areas to support or critique the findings of this study.

\section{REFERENCES}

[1] Amnesty International. (2007). Amnesty International Report 2007: Zimbabwe Amnesty International. Retrieved from http://thereport.amnesty.org/eng on 6th 102015.

[2] Bayley, D. H. (1999). Policing: The world stage. In R.I. Mawby (Ed.), Policing across the world: Issues for the 21st century (pp. 322). London: UCL Press.

[3] Brogden, M., \& Nijhar, P. (2005). Community policing: National and international models and approaches Cullompton: Willan Publishing.

[4] Casey, J. (2010). Policing the World: The Practice of International and Transnational Policing.

[5] Davis, R. C., Henderson, N. J., \& Merrick, C. (2003). Community policing: Variations on the western model in the developing world. Police Practice and Research, 4(3), 285-300.

[6] Dupont, B. (2007). The French police system: Caught between a rock and a hard place -- the tension of serving both the state and the public. In M. R. Haberfeld, \& I. Cerrah (Eds.), Comparative policing: The struggle for democratization (pp. 247-276). Thousand Oaks, CA: Sage.

[7] Fleming, J. (2005). 'Working together': Neighbourhood watch, reassurance policing and the potential of partnerships Canberra: Australian Institute of Criminology. Retrieved from http://www.aic.gov.au/publications/tandi2/tandi303.html

[8] Frühling, H. (2007). The impact of international models of policing in Latin America: The case of community policing. Police Practice and Research, 8 (2), 125-144.

[9] Goldsmith, A., \& Lewis, C. (Eds.). (2000). Civilian oversight of policing: Governance, democracy and human rights. Portland Oregon: Hart Publishing.

[10] Groenewald, H., \& Peake, G. (2004). Police reform through community-based policing philosophy and guidelines for implementation New York: International Peace Academy. Retrieved on $6^{\text {th }} 102015$ from http://www.smallarmssurvey.org/files

[11] Home Office. (2005). Neighborhood policing: Your police; your community; our commitment Home Office Communication Directorate. Retrieved from http://police.homeoffice.gov.uk on $6^{\text {th }} 102015$

[12] Karstedt, S. (2007). Creating institutions: Linking the 'local' and the 'global' in the travel of crime policies. Police Practice and Research, 8 (2), 145-158.

[13] Kempa, M. (2007). Tracing the diffusion of policing governance models from the British Isles and back again: Some directions for democratic reform in troubled times. Police Practice and Research, 8 (2), 107-123.

[14] Lawday, D. (2000). Policing in France and Britain: Restoring confidence locally and nationally Franco-British Council. Retrieved from http://www.francobritishcouncil.org.uk 